Provided for non-commercial research and education use. Not for reproduction, distribution or commercial use.

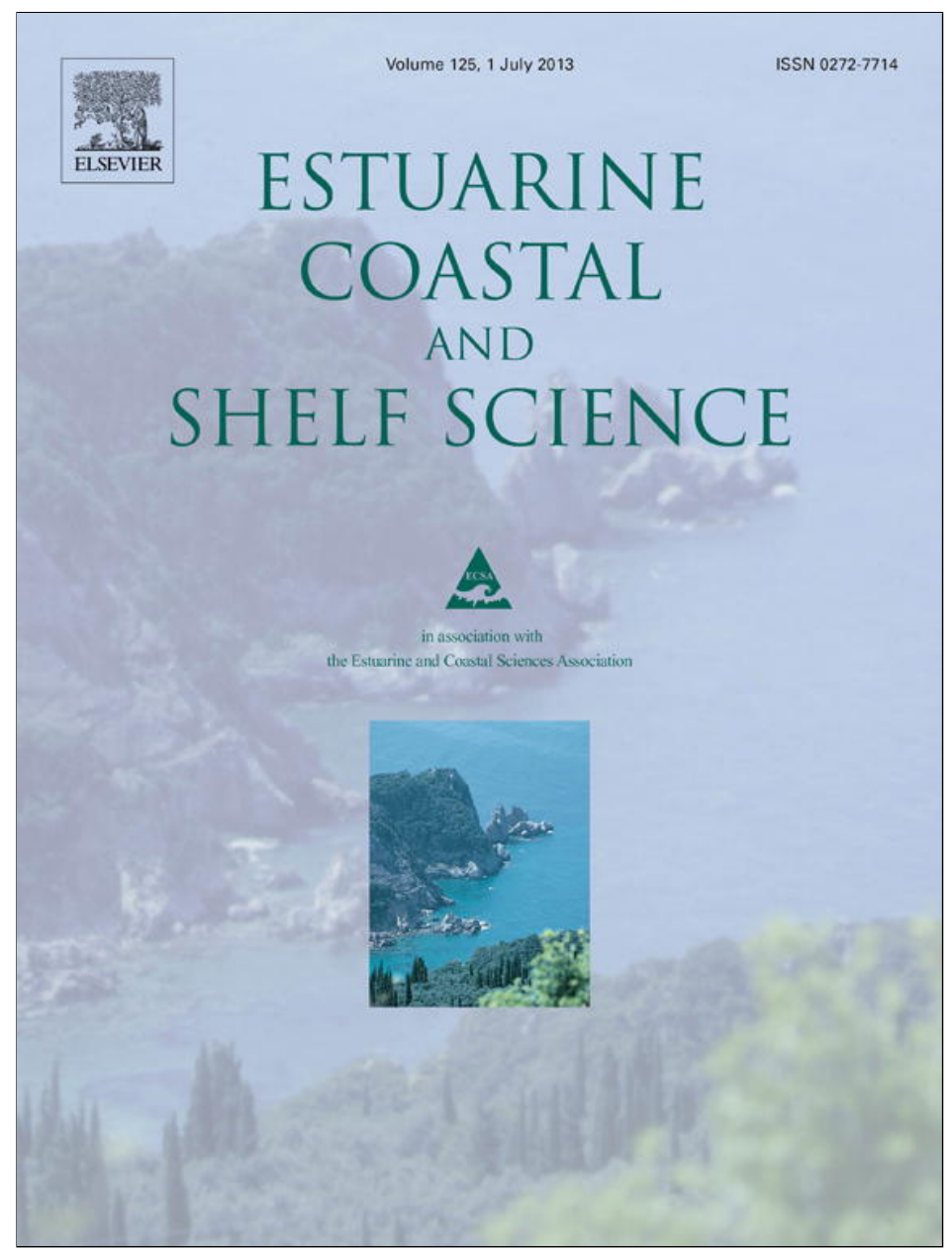

This article appeared in a journal published by Elsevier. The attached copy is furnished to the author for internal non-commercial research and education use, including for instruction at the authors institution and sharing with colleagues.

Other uses, including reproduction and distribution, or selling or licensing copies, or posting to personal, institutional or third party websites are prohibited.

In most cases authors are permitted to post their version of the article (e.g. in Word or Tex form) to their personal website or institutional repository. Authors requiring further information regarding Elsevier's archiving and manuscript policies are encouraged to visit:

http://www.elsevier.com/authorsrights 


\title{
Mobile demersal megafauna at artificial structures in the German Bight - Likely effects of offshore wind farm development
}

\author{
R. Krone ${ }^{\mathrm{a}, *}$, L. Gutow ${ }^{\mathrm{a}}$, T. Brey ${ }^{\mathrm{a}}$, J. Dannheim ${ }^{\mathrm{a}}$, A. Schröder ${ }^{\mathrm{b}}$ \\ ${ }^{a}$ Department of Functional Ecology, Alfred Wegener Institute for Polar and Marine Research, Am Handelshafen 12, 27570 Bremerhaven, Germany \\ ${ }^{\mathrm{b}}$ Department of River Basin Management - Transitional and Coastal Waters, NLWKN Lower Saxony Water Management Agency, Ratsherr-Schulze-Str. 10, 26122 Oldenburg, \\ Germany
}

\section{A R T I C L E I N F O}

Article history:

Received 20 April 2011

Accepted 15 March 2013

Available online 27 March 2013

\section{Keywords:}

habitat creation

shelf sea

soft bottom

offshore platform

wrecks

North Sea

\begin{abstract}
A B S T R A C T
Within the next few decades, large underwater structures of thousands of wind turbines in the northern European shelf seas will substantially increase the amount of habitat available for mobile demersal megafauna. As a first indication of the possible effects of this large scale habitat creation on faunal stocks settling on hard substrata, we compared selected taxa of the mobile demersal megafauna (decapods and fish) associated with the foundation of an offshore research platform (a wind-power foundation equivalent) with those of five shipwrecks and different areas of soft bottoms in the southern German Bight, North Sea. When comparing the amount of approximately 5000 planned wind-power foundations (covering $5.1 \times 10^{6} \mathrm{~m}^{2}$ of bottom area) with the existing number of at least 1000 shipwrecks (covering $1.2 \times 10^{6} \mathrm{~m}^{2}$ of bottom area), it becomes clear that the southern North Sea will provide about 4.3 times more available artificial hard substratum habitats than currently available. With regard to the fauna found on shipwrecks, on soft substrata and on the investigated wind-power foundation, we predict that the amount of added hard substrata will allow the stocks of substrata-limited mobile demersal hard bottom species to increase by $25-165 \%$ in that area. The fauna found at the offshore platform foundations is very similar to that at shipwrecks. Megafauna abundances at the foundations, however, are lower compared to those at the highly fractured wrecks and are irregularly scattered over the foundations. The upper regions of the platform construction ( 5 and $15 \mathrm{~m}$ depth) were only sparsely colonized by mobile fauna, the anchorages, however, more densely. The faunal assemblages from the shipwrecks and the foundations, respectively, as well as from the soft bottoms clearly differed from each other. We predict that new wind-power foundations will support the spread of hard bottom fauna into soft bottom areas with low wreck densities.
\end{abstract}

(c) 2013 Elsevier Ltd. All rights reserved.

\section{Introduction}

The offshore wind energy industry is expanding towards the northern European shelf seas. Where the seafloor in the respective areas is dominated by soft bottoms, i.e. sandy and muddy grounds, all offshore wind-power foundations provide artificial hard substratum habitats which will potentially become colonized by an assemblage of epi- and mobile megafauna, clearly differing from the otherwise prevailing species composition and abundance (Wilhelmsson et al., 2006; Wilhelmsson and Malm, 2008; Langhamer et al., 2009; Lindeboom et al., 2011; Reubens et al.,

\footnotetext{
* Corresponding author.

E-mail addresses: Roland.Krone@awi.de, mail@krone-meereskunde.de (R. Krone), Lars.Gutow@awi.de (L. Gutow), Thomas.Brey@awi.de (T. Brey), Jennifer.Dannheim@awi.de (J. Dannheim), Alexander.Schroeder@NLWKNOL.Niedersachsen.de (A. Schröder).
}

2011; Degraer et al., 2012; Krone et al., 2013). In the North Sea, which is dominated by sandy bottoms, there have been applications for the deployment of 6071 foundations (Schleicher, 2012).

It can be assumed that local stocks of hard bottom settlers, so far limited by the low presence of their preferred habitats in the open North Sea, will increase in the future (Wilson and Elliott, 2009). This will lead to a change in the epibenthos and the mobile demersal megafauna (MDM)-communities in the North Sea for which to date the dimensions and effects on the autochthone fauna are very difficult to assess.

Together with the macrozoo-epibenthos settling on artificial constructions (fouling), which can be viewed as the central trigger of reef effects (Lindeboom et al., 2011; Krone, 2012), the MDM is an important functional group including numerous predators that potentially control the epibenthos (Freire and González-Gurriarán, 1995; Relini et al., 2002; Baum and Worm, 2009; McCauley et al., 2010). Some typical MDM hard bottom species, for example the 
edible crab Cancer pagurus and the European lobster Homarus gammarus are even of commercial importance.

The change in the faunal composition, however, will take place in a marine area which already has undergone anthropogenic structural changes: decades before the establishment of any wind-power foundations thousands of shipwrecks in wide areas of the North Sea and some oil and gas-rigs in the central North Sea have provided substantial amounts of artificial hard substrata habitats on the seafloor (Kingsbury, 1981; Leewis et al., 2000; Zintzen et al., 2008b; Krone and Schröder, 2011). Numerous studies from different areas globally have shown that wrecks and offshore platforms are permanently colonized by typical hard bottom faunal communities and are frequented by such species foraging on such fouling (Wolfson et al., 1979; Stephan and Lindquist, 1989; Page et al., 1999; Jørgensen et al., 2002; Løkkeborg et al., 2002; Arena et al., 2007).

In order to assess the relevance of the constructional development of wind-power foundations in a shelf sea such as the North Sea for the MDM, it is also necessary to quantify faunal communities already established on the numerous older shipwrecks and to compare those to the autochthon communities from the prevailing seabeds. Most studies in the North Sea in which the biota on artificial structures have systematically been quantified, however, focused on biofouling communities (Forteath et al., 1982; Whomersley and Picken, 2003; Zintzen et al., 2006; Joschko et al., 2008; Wilhelmsson and Malm, 2008; Zintzen et al., 2008a; Hiscock et al., 2010; Zintzen and Massin, 2010; Krone et al., 2013) or selected megafauna species (Reubens et al., 2011). To date, there are only semi-quantitative records of mobile crustaceans and fish species often abounding at shipwrecks and wind-power foundations in the North Sea (Hiscock, 1980; Leewis et al., 2000; Massin et al., 2002; Bouma and Lengkeek, 2012).

To our knowledge, there are no previous systematic quantitative recordings, allowing for comparisons between fauna from soft bottoms, shipwrecks, and offshore foundations in the same area and thereby assessing the relevance of the plentiful introductions of wind-power foundations in a shelf sea such as the North Sea for the MDM stocks. It is as yet unknown whether offshore wind-power foundations will simply add to the existing pool of wrecks or whether they will represent a new artificial habitat to the benthic system. Wind-power constructions differ from wrecks in that they reach through the entire water column while wrecks usually extend only a few metres above the seafloor. Previous studies have shown that water depth, gradients in light intensity and wave force are important structuring factors for epifaunal assemblages on natural and artificial hard substrata (Castric and Chasse, 1991; Whomersley and Picken, 2003). Particularly in deeper offshore waters, windpower foundations will therefore provide a more heterogeneous habitat with regard to water depth and light intensity distribution than wrecks and might be inhabited by a qualitatively and quantitatively different biota (Krone et al., 2013).

In the German Exclusive Economic Zone (EEZ, comprising the German Bight) a total of about 5000 single wind turbines are planned for construction within the next two decades (IEA, 2008; Krone, 2012; RAVE, 2013). The wind farms in the German Bight will provide numerous artificial hard substratum in areas which are naturally dominated by soft bottoms where the island of Helgoland and few glacial bolder reefs provide the only natural subtidal hard bottom habitats (Figge, 1981). More than 1000 wrecks have been registered in coastal and offshore waters of the German EEZ (Krone and Schröder, 2011). In the southern German Bight the research platform FINO 1 was erected in 2003 on a so-called jacket foundation which is very similar to the constructions of offshore windpower foundations. The platform is situated in an area where the water depth allows for assessing quantitative MDM-abundances via scuba diving. At the same time, detailed wreck reports allow for secure diving on site for investigations of the respective wrecks in the same area.

The present study, conducted within the soft area of future wind farms in close vicinity to the research platform FINO 1 and at several shipwrecks at a maximum water depth of $33.5 \mathrm{~m}$ in the southern German Bight, addressed the following questions: (1) What are the abundances and population structures of the MDM communities on a submerged foundation equivalent to a wind-power foundation, on shipwrecks and autochthonous soft substrata? (2) Are there qualitative and quantitative differences in the MDM communities between the wrecks and the foundation? (3) For which and for how many species of the MDM in the North Sea will the construction and deployment of wind-power foundations provide new habitats and hence increase a so far habitat-limited carrying capacity?

\section{Materials and methods}

We catalogued the MDM $(\geq 1 \mathrm{~cm})$ on the submerged construction of the offshore research platform FINO 1, five wrecks and the open soft bottom (also referred to as soft substrata) in the German Bight (southern North Sea). FINO 1 was built to measure biological and physical parameters relevant for the operation of offshore wind farms. The underwater construction of the platform is similar in size and shape to the common jacket type foundations of wind turbines in the German Bight. It is, therefore, considered a windpower foundation equivalent which allows for drawing direct conclusions on the implications of the underwater constructions of offshore wind-power constructions on marine biota.

\subsection{Study sites}

From summer 2007 to spring 2009 visual censuses were performed on the MDM on four shipwrecks and a sunken floating dock, the underwater construction of the offshore research platform FINO 1, and on soft bottom (Fig. 1, Table 1). The four-legged steel underwater construction of FINO 1 rests on the seafloor and is anchored by four pylons driven through sleeves (anchorages) in each corner of the foundation (for details compare Joschko et al., 2008; Krone et al., 2013). The soft bottom MDM was surveyed at 21 reference positions scattered around the wrecks and the platform. Furthermore, 366 beam trawl catches distributed over the German Bight were used to gain approximate information on MDM stocks of the entire German EEZ.

\subsection{Diving censuses}

To quantify the MDM on the wrecks and FINO 1 visual censuses were conducted by airline-supported scientific diving around slack water. It was not possible to conduct the recordings on the wrecks, the soft bottom and the research platform all at the same time in each year and season. Despite this, we were able to sample records from all sites within the time frame of three years (Table 1 ).

On each wreck the MDM was recorded in total by three to four $15 \times 1 \times 1 \mathrm{~m}$ transects (Table 2 ). Transect length was controlled by a $15 \mathrm{~m}$ transect line. Transect widths and heights were controlled by a $1 \mathrm{~m}$-spacer clipped to the line reel. The transects stretched linearly above the wreck in random directions from where the diver first hit the wreck, thereby ignoring minor three dimensional structures of the wreck surface. The diver stopped every marked metre along the transect to search the cubic metre ahead for fishes and mobile decapod crustaceans (Wilhelmsson et al., 2006). If a transect extended beyond the wreck area, the diver changed direction at the edge of the wreck to complete the transect within the wreck area (Fig. 2A). Small interspersed patches (approx. 0.25$2.25 \mathrm{~m}^{2}$ ) of sediment among wreck fragments were not excluded 


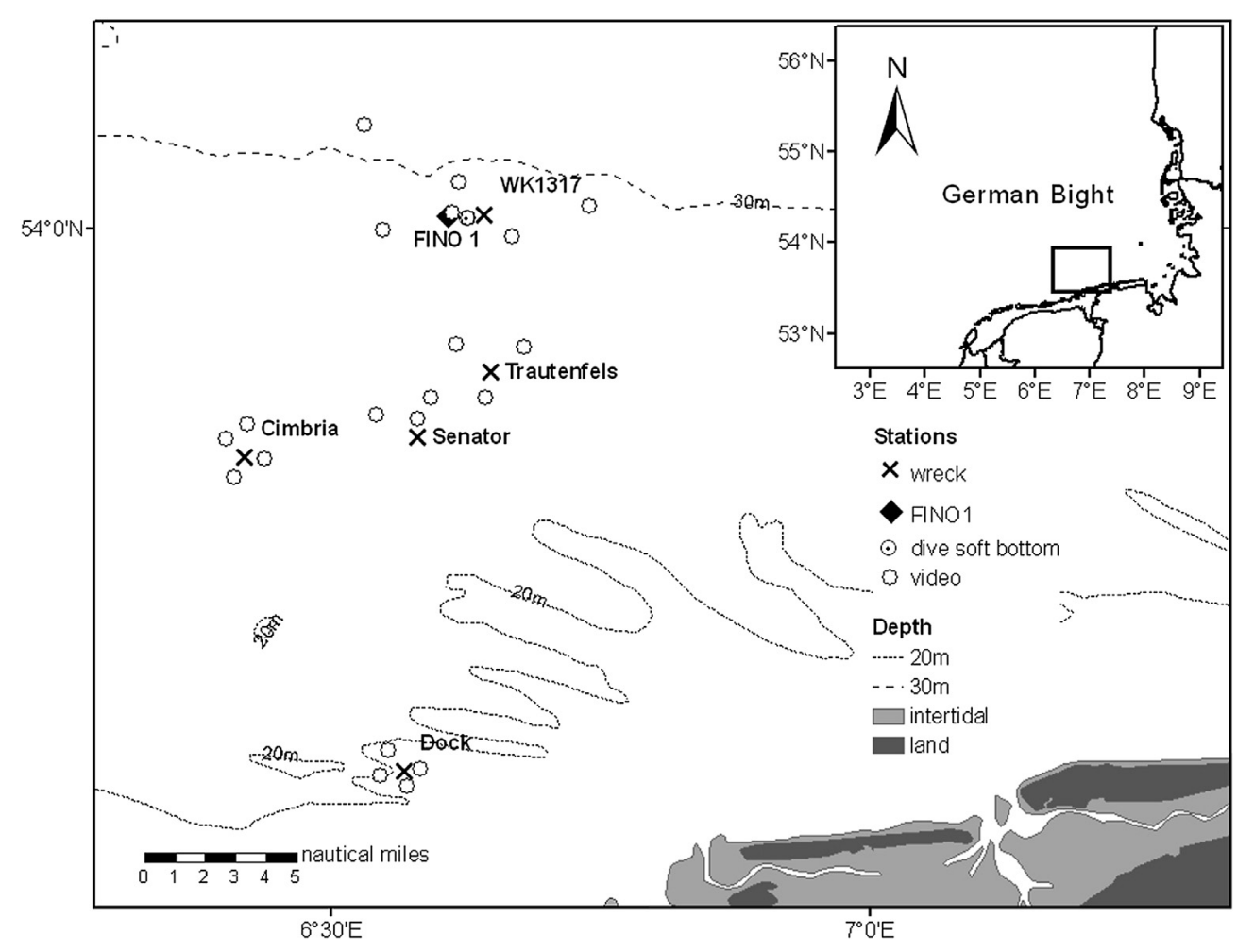

Fig. 1. Geographic positions of the investigated wrecks, the research platform FINO 1, and soft sediment stations in the south-western German Bight.

from the transects. The insides of the ship hulls (if present) were not surveyed for safety reasons. All individuals were counted and identified in situ to the lowest taxonomic level possible. Each record was reported to a co-worker at the surface via underwater telephone. All organisms counted within a $15 \mathrm{~m}^{3}$ transect were assigned to a projection area of $15 \mathrm{~m}^{2}$.

At the research platform FINO 1 the MDM was quantified between summer 2007 and spring 2009 by a total of 29 transects (Table 2). The search technique was adapted to the specific architecture of the jacket structure. Four different sections of the jacket were identified: tube junctions in 5 and $15 \mathrm{~m}$ water depth (joining a near vertical main tube, two horizontal and one diagonal tube), bottom anchorages (at this section two horizontal, one vertical and one diagonal tube join; a broad but short vertical tube is attached, through which a pylon is driven into the seafloor), and the nearby seafloor (Fig. 2B). Junctions and anchorages including $1 \mathrm{~m}$ of each joining tube were searched and recorded entirely together with the adjacent water body to a distance of $1 \mathrm{~m}$. The diagonal and vertical tubes of the jacket structure were not surveyed quantitatively. As with the wrecks, abundances of the megafauna were referred to the projected surface area of the platform sections. Thereby, we ignored structural peculiarities such as for example the bulged surface of cylindrical tubes or cable channels. The projection area of each platform section was calculated from architectural drawings and was $32 \mathrm{~m}^{2}$ for each anchorage and $11 \mathrm{~m}^{2}$ for each junction.

For nearby bottom transects (FINO 1 ground) we applied the same $15 \mathrm{~m}^{3}$ line transect method as for the wrecks. Each transect started $1 \mathrm{~m}$ distance from a bottom anchorages to avoid spatial overlap with the $1 \mathrm{~m}$ search space around the anchorages and stretched from there into haphazard directions away from the jacket. For safety

Table 1

Characteristics of the investigated wrecks, the research platform FINO 1, and soft sediment sites.

\begin{tabular}{|c|c|c|c|c|c|c|c|}
\hline & Cimbria & Trautenfels & Senator & Dock & WK 1317 & FINO 1 & Soft bottom \\
\hline $\begin{array}{l}\text { Founding resp. sinking } \\
\text { [year] }\end{array}$ & 1883 & 1942 & 1979 & 1991 & Before 1982 & 2003 & - \\
\hline \multirow[t]{2}{*}{ Coordinates } & $53^{\circ} 52.6^{\prime} \mathrm{N}$ & $53^{\circ} 55.7^{\prime} \mathrm{N}$ & $53^{\circ} 53.4^{\prime} \mathrm{N}$ & $53^{\circ} 42.4^{\prime} \mathrm{N}$ & $54^{\circ} 00.9^{\prime} \mathrm{N}$ & $54^{\circ} 00.8^{\prime} \mathrm{N}$ & Sea map \\
\hline & $6^{\circ} 24.3^{\prime} \mathrm{E}$ & $6^{\circ} 37.8^{\prime} \mathrm{E}$ & $6^{\circ} 33.9^{\prime} \mathrm{E}$ & $6^{\circ} 33.8^{\prime} \mathrm{E}$ & $6^{\circ} 37.2^{\prime} \mathrm{E}$ & $6^{\circ} 35.2^{\prime} \mathrm{E}$ & \\
\hline Type & Steam sailor & Cargo ship & Fishing boat & Floating dock & Fishing boat & $\begin{array}{l}\text { Jacket construction, } \\
\text { nearby seafloor }\end{array}$ & - \\
\hline Material & $\begin{array}{l}\text { Wood and } \\
\text { Steel }\end{array}$ & Steel & $\begin{array}{l}\text { Wood and } \\
\text { glass fibre }\end{array}$ & Steel & Steel & $\begin{array}{l}\text { Jacket: steel; Seafloor: } \\
\text { massive shell top layer }\end{array}$ & $\begin{array}{l}\text { Fine to coarse } \\
\text { sand }\end{array}$ \\
\hline $\begin{array}{l}\text { Depth below chart } \\
\text { datum }[\mathrm{m}]\end{array}$ & 24.5 & 25.5 & 24.4 & 18.5 & 33.5 & 28.0 & $32.4-20.5$ \\
\hline Max. wreck height [m] & 4.9 & 7 & 5.5 & 1.8 & 5.8 & Up to sea level & - \\
\hline Length $[\mathrm{m}]$ & 101 & 140 & 24 & 70 & 40 & 32 on ground & - \\
\hline Width [m] & 12 & 50 & 6 & 35 & 6 & 32 on ground & - \\
\hline $\begin{array}{l}\text { Investigation periods } \\
\text { [month/year] }\end{array}$ & $\begin{array}{l}04 / 08 \text { and } \\
08 / 08\end{array}$ & $08 / 07$ & $08 / 07$ & $10 / 07$ & $04 / 09$ & 08/07 and 04/09 & $08 / 07$ and $10 / 07$ \\
\hline Orientation & $\mathrm{E} / \mathrm{W}$ & $\mathrm{N} / \mathrm{S}$ & SSE/NNW & $\mathrm{N} / \mathrm{S}$ & NNE/SSW & - & - \\
\hline Condition & $\begin{array}{l}\text { Expanse } \\
\text { of ruins }\end{array}$ & $\begin{array}{l}\text { Expanse } \\
\text { of ruins }\end{array}$ & $\begin{array}{l}\text { Massive, broken } \\
\text { in two parts }\end{array}$ & $\begin{array}{l}\text { Walls toppled } \\
\text { over }\end{array}$ & $\begin{array}{l}\text { Expanse of } \\
\text { ruins }\end{array}$ & - & - \\
\hline
\end{tabular}


Table 2

List of species and densities (mean $\pm \mathrm{SD}$, no. of ind. $\mathrm{m}^{-2}$ and total calculated numbers inside the "footprint" area) of the megafauna on dive and video transects at wrecks, junctions and anchorages of the research platform FINO 1, and soft sediment areas in the German Bight.

\begin{tabular}{|c|c|c|c|c|c|c|c|c|c|}
\hline & \multicolumn{6}{|c|}{ Densities $\left[\mathrm{n} \mathrm{m}^{-2}\right]$} & \multicolumn{3}{|c|}{ Calculated absolute numbers } \\
\hline & Wrecks & Anchorages & $15 \mathrm{~m}$ Junction & $5 \mathrm{~m}$ Junction & FINO ground & Soft bottom & $\begin{array}{l}\text { Wreck } \\
\left(1200 \mathrm{~m}^{2}\right)\end{array}$ & $\begin{array}{l}\text { FINO1 } \\
\left(1024 \mathrm{~m}^{2}\right)\end{array}$ & $\begin{array}{l}\text { Soft bottom } \\
\left(1200 \mathrm{~m}^{2}\right)\end{array}$ \\
\hline \multicolumn{10}{|l|}{ Crustacean } \\
\hline Pagurus bernhardus & $0.13 \pm 0.26$ & $0.43 \pm 0.56$ & & & $0.68 \pm 0.48$ & $0.06 \pm 0.06$ & 156 & 751 & 72 \\
\hline Homarus gammarus & $0.003 \pm 0.01$ & & & & & & 4 & & \\
\hline Corystes cassivelaunus & & & & & & $0.003 \pm 0.01$ & & & 4 \\
\hline Necora puber & $0.49 \pm 0.37$ & $0.58 \pm 0.25$ & $0.13 \pm 0.21$ & & $0.11 \pm 0.09$ & & 588 & 193 & \\
\hline Liocarcinus spp. & $0.01 \pm 0.02$ & $0.35 \pm 0.37$ & & $0.03 \pm 0.06$ & $1.17 \pm 0.88$ & $0.29 \pm 0.34$ & 12 & 1244 & 348 \\
\hline Cancer pagurus & $1.52 \pm 0.92$ & $0.34 \pm 0.14$ & $0.01 \pm 0.04$ & $0.01 \pm 0.03$ & $0.17 \pm 0.14$ & & 1824 & 218 & \\
\hline \multicolumn{10}{|l|}{ Fish } \\
\hline Trisopterus luscus & $2.20 \pm 3.86$ & $0.17 \pm 0.37$ & & & & $0.003 \pm 0.01$ & 2640 & 22 & 4 \\
\hline Gadus morhua & $0.06 \pm 0.09$ & & & & & & 72 & & \\
\hline Merlangius merlangus & $0.12 \pm 0.39$ & $0.04 \pm 0.09$ & & & & & 144 & 5 & \\
\hline Ciliata mustela & & $0.01 \pm 0.01$ & & & & & & 1 & \\
\hline Pholis gunellus & $0.01 \pm 0.03$ & $0.03 \pm 0.01$ & & & $0.01 \pm 0.03$ & & 12 & 14 & \\
\hline Parablennius gattorugine & $0.01 \pm 0.03$ & & & $0.01 \pm 0.03$ & & & 12 & 0.4 & \\
\hline Gobiidae indet. & $0.06 \pm 0.14$ & & & & $0.30 \pm 0.29$ & $0.48 \pm 0.41$ & 72 & 307 & 576 \\
\hline Ctenolabrus rupestris & $0.54 \pm 0.88$ & $0.01 \pm 0.03$ & & & & & 648 & 1 & \\
\hline Callionymus spp. & $0.01 \pm 0.02$ & & & & $0.33 \pm 0.24$ & $0.09 \pm 0.15$ & 12 & 338 & 108 \\
\hline Trachurus trachurus & & & & & & $0.01 \pm 0.02$ & & & 12 \\
\hline Mullus surmuletus & & & & & & $0.003 \pm 0.02$ & & & 4 \\
\hline Pleuronectes platessa & & & & & & $0.03 \pm 0.04$ & & & 36 \\
\hline Other flat fishes & & $0.02 \pm 0.03$ & & & $0.15 \pm 0.20$ & $0.09 \pm 0.16$ & & 156 & 108 \\
\hline Triglidae indet. & & & & & $0.01 \pm 0.03$ & & & 10 & \\
\hline Taurulus bubalis & $0.14 \pm 0.16$ & $0.30 \pm 0.20$ & $0.03 \pm 0.07$ & & & & 168 & 40 & \\
\hline Myoxocephalus scorpius & $0.003 \pm 0.01$ & $0.02 \pm 0.04$ & & & & & 4 & 3 & \\
\hline Agonus cataphractus & $0.003 \pm 0.01$ & $0.01 \pm 0.03$ & & & & & 4 & 1 & \\
\hline Syngnathidae indet. & & $0.01 \pm 0.01$ & & & & $0.01 \pm 0.03$ & & 1 & 12 \\
\hline Total taxon number & 16 & 14 & 3 & 3 & 9 & 11 & & & \\
\hline Average taxa per sample & $4.9 \pm 1.1$ & $7.2 \pm 1.7$ & $0.8 \pm 1.0$ & $0.5 \pm 0.8$ & $6.0 \pm 1.4$ & $4.3 \pm 1.5$ & & & \\
\hline Number of samples & 23 & 6 & 6 & 7 & 7 & 21 & & & \\
\hline
\end{tabular}

reasons, the area beneath the jacket structure was not surveyed. $26 \mathrm{~W}$ halogen underwater torches were used for searching the anchorages, the $15 \mathrm{~m}$ junctions and the bottom transects but not for the $5 \mathrm{~m}$ junctions. Three $5 \mathrm{~m}$ junctions, three $15 \mathrm{~m}$ junctions, three anchorages and four bottom transects were investigated in August 2007. In April 2009 we sampled four $5 \mathrm{~m}$ junctions, three $15 \mathrm{~m}$ junctions, three anchorages and three bottom transects.

\subsection{Reference soft bottom video transects}

The MDM on natural soft substrata (soft bottom) was surveyed by a ship-based underwater video camera system (CMOS video TV resolution with $9 \mathrm{~W}$ high power LED light) towed over ground at a drift speed of $0.2-0.5$ knots. On drift transects of $500 \mathrm{~m}$ length the camera was positioned a few decimetres above the seafloor. The camera was equipped with parallel lasers $7 \mathrm{~cm}$ apart from each other to allow for quantitative analysis of the videos. For the analysis we counted animals on approx. $21 \mathrm{~cm}$ wide strips. To obtain transects of $15 \mathrm{~m}^{2}$, sections of about $71 \mathrm{~m}$ in length were randomly selected from each video. To compare dive transects and video transects we sampled two dive transects ( $15 \mathrm{~m}^{2}$ each) in August 2007 on soft bottom that was previously surveyed by the underwater camera.

\subsection{MDM abundances on soft sediments: beam trawl catches}

In order to assess the stocks of MDM species which colonized wrecks and the foundation of FINO 1 for the entire German EEZ, 366
A

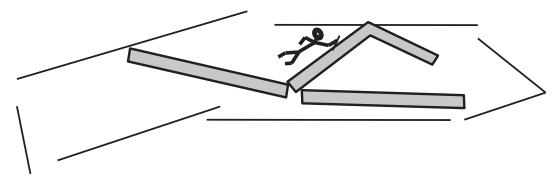

B

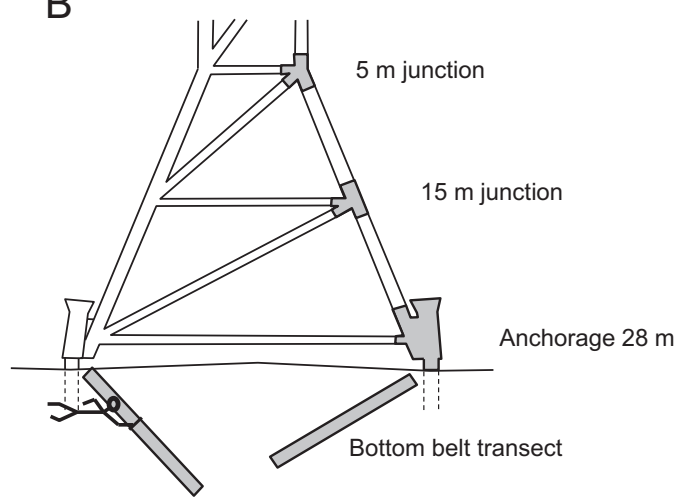

Fig. 2. Schematic drawing of dive transects at shipwrecks (A) and the jacket structure of the research platform FINO 1 (B). The diver was connected to the surface via telephone cable and air support. Wrecks and the seafloor around FINO 1 were searched by belt transects ( $1 \mathrm{~m}$ width, $15 \mathrm{~m}$ length, $1 \mathrm{~m}$ height). Anchorages and junctions of the research platform FINO 1 were searched entirely. Abundances of the megafauna were referred to the projection areas of the platform sections and the $15 \mathrm{~m}^{2}$ projection area of the line transects. 
beam trawl catches from various locations distributed over the German Bight were conducted (length $789 \pm 289$ m, trawling speed 3 knots, opening 2-3 m, cod-end mesh size $1 \mathrm{~cm}$ ) between 2000 and 2010, and analyzed (Supplementary Material). Methodologicallycaused differences between the recordings of the MDM via beam trawl catches and scuba diving were neglected, because a quantitative recording of MDM via scuba diving in the entire German Bight is not possible.

\subsection{Data analysis}

When video recording the soft bottom, individual animals are not as easily identified to species level as on dive transects. In order to compare the fauna from the soft bottom with that from the wrecks and the research platform foundation, the data from the diving events were used only to the taxonomic level achieved via video recording. Species of the taxa Gobiidae, Syngnathidae, Triglidae, flat fishes (Pleuronectiformes except for Pleuronectes platessa) and swimming crabs (except for the velvet crab Necora puber) were not fully distinguishable by both in situ and video records and were summarized on these higher taxonomic levels.

Because of the limited number and heterogeneous nature of the samples, data analysis was conducted using non-parametric approaches. Prior to analysis the sample data were square root transformed to reduce the influence of highly abundant species (Clarke and Warwick, 2001). For the following community analyses, six separate habitats were defined (Table 2): wreck, anchorage (FINO 1), $15 \mathrm{~m}$ junction (FINO 1), $5 \mathrm{~m}$ junction (FINO 1), FINO ground and soft bottom. Differences between these habitats were visualized by non-metric multi-dimensional scaling (nMDS) based on Bray-Curtis similarities. Each sample was treated separately and equally and the samples were not distinguished with regard to their recordings from different times of season and year. To detect habitat specific variations, the MDM community was analyzed by a one way ANalysis Of SIMilarity ANOSIM (factor: habitat). Taxa which contributed most to the dissimilarities between habitats were identified by the SIMilarity PERcentage procedure (SIMPER). No MDM were found on four out of seven $5 \mathrm{~m}$ junctions and on three out of six $15 \mathrm{~m}$ junction samples of the platform FINO 1. These nil samples were excluded from the analysis. The analyses were carried out using PRIMER $^{\mathrm{TM}}$ v 6.0 (Clarks and Gorley, 2006).

We then calculated the total number of individuals on the bottom area which is covered by the artificial structures ('footprint'). For the wrecks, the average density (per $\mathrm{m}^{-2}$ ) of each taxon was multiplied by an average North Sea wreck 'footprint' of $1200 \mathrm{~m}^{2}$ (Krone and Schröder, 2011). The average abundance of each taxon on each jacket section was multiplied by their number of the respective platform section of FINO 1, summed up and projected on the 'footprint' (1024 $\mathrm{m}^{2}$ between the pylons). The number of specimens living on the seafloor between the jacket pylons was adopted from the bottom transects performed adjacent to FINO 1.

In order to estimate absolute abundances for the German EEZ in the North Sea, the number of the MDM species found in the beam trawl catches was averaged $\left(\mathrm{n} \mathrm{m}^{-2}\right)$ and multiplied by the size of the respective area, i.e. $28,539 \mathrm{~km}^{2}$ (including the few small hard substratum areas). The abundances of the MDM which were detected in the area around FINO 1 at the platform foundation and at the shipwrecks, but not on the open soft bottom, were extrapolated to the amount of 1000 wrecks in the German EEZ (roughly the German Bight) and to a number of 5000 prospective windpower foundations. These abundances were viewed in relation to the total abundances recorded for the beam trawl catches from the soft bottom area in the EEZ.

\section{Results}

A total of 24 taxa ( 6 crustaceans, 18 fishes) were identified in this study (Table 2). We found 20 taxa on the hard substratum habitats (wrecks and FINO 1 sections). 15 taxa were recorded on the soft bottom around FINO 1 and the open soft bottom area. 9 taxa occurred exclusively on the artificial structures while 5 taxa occurred on the soft bottom only. The number of taxa on FINO 1, including anchorages (14 taxa), $5 \mathrm{~m}$ junctions ( 3 taxa) and $15 \mathrm{~m}$ junctions ( 3 taxa), was 15 . A total of 16 taxa were found on the wrecks and 11 taxa were found on the soft bottom video transects.

The dominant taxa on the hard substrata were the edible crab Cancer pagurus and the pouting Trisopterus luscus. Large C. pagurus of up to $25 \mathrm{~cm}$ carapace width aggregated only on wrecks and at the anchorages of the FINO 1 . At shallower depths (5 and $15 \mathrm{~m}$ depth) only small individuals (max. $5 \mathrm{~cm}$ carapace width) were found resting within the fouling assemblages (mostly dominated by the cnidarians Metridium senile). A single European lobster (Homarus gammarus) was found on the wreck of the 'Cimbria'. Few tompot blennies (Parablennius gattorugine) occurred at the research platform and on a single wreck. Portunid crabs (Liocarcinus spp.) were the most common taxon on the soft bottom with higher abundances closer to the platform than farther away from it, i.e. on open bottoms.

Three major megafaunal clusters were evident from the nMDSplot (Fig. 3). The first cluster comprises the samples from open soft bottoms. Soft bottom samples obtained from underwater videos and from in situ diving censuses were indistinguishable from each other confirming that the separation of the open bottom cluster from all other clusters was not a methodical artifact but reflects actual structural differences. Callionymus spp., Pagurus bernhardus, Liocarcinus spp. and Gobiidae contributed together almost 100\% to the similarity between the soft bottom transects. The Gobiidae alone accounted for approx. 50\% of the similarity. Together with Liocarcinus spp. (approx. 30\% contribution) they numerically dominated the open soft bottom (Table 2).

The second cluster was represented by hard substrata samples from the wrecks and the platform anchorages. The wreck and anchorage samples showed a strong compositional overlap with a small yet significant difference (Table 3 ). Cancer pagurus and Necora puber accounted for $67 \%$ of the similarity between the samples from these two artificial habitats. The separation from the open soft bottom samples was due to the higher abundance of C. pagurus, N. puber and the gadoid Trisopterus luscus on the hard

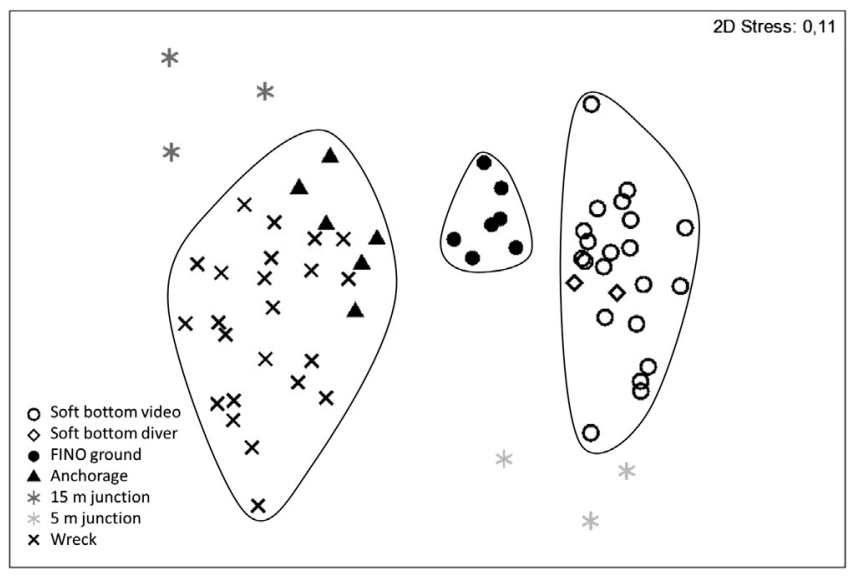

Fig. 3. 2D-nMDS-plot showing Bray-Curtis dissimilarities among megafauna communities from wrecks, junctions and anchorages of the research platform FINO 1, and from soft sediment areas in the German Bight. Abundance data were square root transformed. 
Table 3

Results of the ANOSIM ( $R$ values; $0=$ no differences between groups, $1=$ groups totally separated) comparing megafauna communities from wrecks, junctions and anchorages of the research platform FINO 1, and soft sediment areas in the German Bight. Abundance data were square root transformed. Asterisks denote for significance differences at $\alpha=0.05$.

\begin{tabular}{llllll}
\hline & Wreck & $\begin{array}{l}\text { FINO } \\
\text { ground }\end{array}$ & Anchoring & $\begin{array}{l}15 \mathrm{~m} \\
\text { Junction }\end{array}$ & $\begin{array}{l}5 \mathrm{~m} \\
\text { Junction }\end{array}$ \\
\hline FINO ground & $0.84^{*}$ & & & & \\
Anchoring & $0.30^{*}$ & $0.90^{*}$ & & & \\
15 m Junction & $0.80^{*}$ & $1.00^{*}$ & $0.81^{*}$ & & \\
5 m Junction & $0.99^{*}$ & $1.00^{*}$ & $1.00^{*}$ & 0.94 & \\
Soft bottom & $1.00^{*}$ & $0.49^{*}$ & $0.98^{*}$ & $1.00^{*}$ & $0.83^{*}$ \\
\hline
\end{tabular}

substrata and higher abundances of gobies on the soft bottom. The SIMPER routine revealed that each of these taxa contributed more than $10 \%$ to the total dissimilarity between the samples from open soft bottom and the hard substrata. The third cluster takes an intermediate position in the nMDS-plot and covers the samples from the bottom transects adjacent to the platform (FINO ground).

Around the platform foundation a scour extended at least $15 \mathrm{~m}$ away from the platform. The maximum depth of the scour was about $2 \mathrm{~m}$ and levelled out towards the edges. Close to the jacket anchorages, the bottom was covered by a thick shell layer. Scours around the wrecks were also covered by shell layers. The bottom samples from around FINO 1 were distinguishable from the hard substratum samples of the wrecks and the platform by the occurrence of typical soft sediment species such as flatfish, gobiids and callionymids, as well as by higher densities of Liocarcinus spp. and the hermit crab Pagurus bernhardus (Table 3). They differed from the hard substrata samples by lower densities of Cancer pagurus and Trisopterus luscus. Each of these taxa contributed more than $10 \%$ of the dissimilarity between the clusters. The third cluster showed small but significant differences to the open soft bottom cluster. Typical soft bottom species were common on both the seafloor around FINO 1 and the open soft bottom. However, densities of Portunidae were four times higher around the jacket structure while on the open soft bottom 1.6 times more Gobiidae were detected.

The samples of the platform from the $15 \mathrm{~m}$ junctions and from the $5 \mathrm{~m}$ junctions could not be assigned to any of the three clusters because of the overall low megafauna abundance at the junctions. The samples from the $15 \mathrm{~m}$ junctions were more similar to the hard substratum samples of the wrecks and the anchorages. The only three species (Cancer pagurus, Necora puber and Taurulus bubalis) from the $15 \mathrm{~m}$ junctions were also found on the wrecks and at the platform anchorages but not on the soft bottom. On the $5 \mathrm{~m}$ junctions, we found a single Parablennius gattorugine, one small C. pagurus and a single Liocarcinus spp.

Calculated abundances of Taurulus bubalis were four times higher on the average 'footprint' area of a wreck than on the 'footprint' area of the FINO 1 structure (Fig. 4). Numbers of Necora puber and Cancer pagurus were three and eight times, respectively, higher on wrecks than at the platform. More than 1000 wrecks inside the German EEZ add about $1.2 \times 10^{6} \mathrm{~m}^{2}$ 'footprint' area of hard substrata to the prevailing North Sea bottoms. They provide habitat for extrapolated numbers of $1.8 \times 10^{6} \mathrm{C}$. pagurus, $5.9 \times 10^{5}$ $N$. puber and $1.7 \times 10^{5} \mathrm{~T}$. bubalis. 5000 jacket foundations of the FINO 1 type would add a footprint area of artificial hard substrata of $5.1 \times 10^{6} \mathrm{~m}^{2}$ to the German EEZ creating potential habitat for $1.1 \times 10^{6} \mathrm{C}$. pagurus, $9.7 \times 10^{5} \mathrm{~N}$. puber and $2.0 \times 10^{5} \mathrm{~T}$. bubalis. The analysis of 366 beam trawl catches sums up to abundances of 2430000 C. pagurus $\left(8.5 \times 10^{-5} \pm 4.9 \times 10^{-4} \mathrm{n} \mathrm{m}^{-2}\right), 0 \mathrm{~N}$. puber, and 0 T. bubalis for the entire EEZ (including non-fishable rocky substratum).

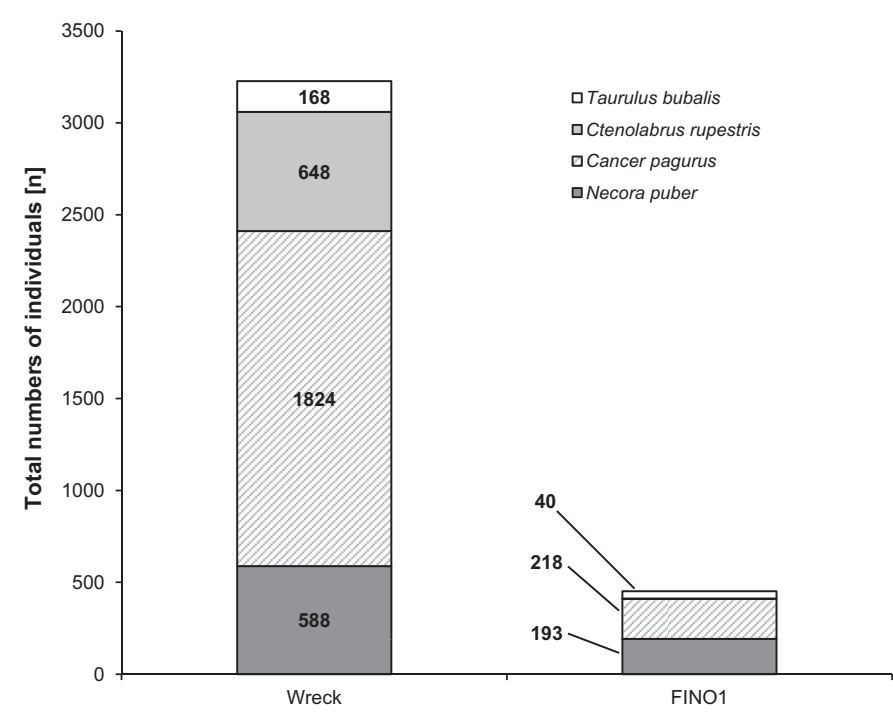

Fig. 4. Extrapolated total abundances of dominant megafauna species at a standardized wreck (area: $1200 \mathrm{~m}^{2}$ ) and the projected area of the research platform FINO 1 (area: $1024 \mathrm{~m}^{2}$ ) (only those species with $>0.3$ ind. $\mathrm{m}^{-2}$, which did not occur on soft sediments were included).

\section{Discussion}

Numerous wind turbines with underwater structures comparable to the investigated jacket construction will be established in future North Sea wind farms. In the German Bight more than 5000 foundations will numerically exceed by far the ca.1000 wrecks which already exist in this region. Both types of artificial structures provide habitat for a hard substratum fauna which is otherwise restricted to the sparse rocky habitats scattered within the extensive soft bottoms or which occur in very low numbers on the very extensive soft bottom plains of the German Bight. The MDM assemblages from the soft bottoms, the wrecks and from various sections of the research platform foundation can be divided into two major groups: the fauna typical for solid structures and the fauna typical for soft bottoms. The assemblage from the platform construction was clearly different from the assemblage of the soft sediments, similar to observations made in other studies of artificial constructions and reefs (e.g. Wilhelmsson and Malm, 2008). Similar assemblages occurred on the wrecks and on the anchorages of the platform while the upper sections of the platform constructions were largely free of MDM. We therefore suggest that the underwater constructions of offshore wind turbines will generally provide habitat for MDM assemblages which are also found on wrecks.

\subsection{Wrecks}

The wrecks in the German Bight serve as habitats for an abundant and diverse fauna and are, thus, similar to wrecks from the Atlantic coast of North America (Stephan and Lindquist, 1989; Arena et al., 2007) and from waters of the Netherlands and Belgium (Leewis et al., 2000; Massin et al., 2002; Zintzen et al., 2008b). Some of the very abundant taxa are obligatorily associated with hard bottom (e.g. Necora puber) or are clearly less abundant on soft bottoms such as Cancer pagurus. C. pagurus is a facultative resident on hard substrata and in particular large adults migrate over soft and rocky substrata in search for food and mates. The omnivorous crabs feed on other decapod crustaceans on rocky substrata such as Pilumnus hirtellus, on bivalves Mytilus edulis and Crassostrea gigas and on young conspecifics (Lawton, 1989; Mascaró and Seed, 2001) and on invertebrates 
from soft sediments (e.g. Cerastoderma edule). Breeding female C. pagurus prefer a heterogeneous seabed of sand and bolders or rocks. Inside the German Bight the velvet crab N. puber occurs frequently on the rocky substratum of the island of Helgoland (Harms, 1993). Necora puber is an aggressive omnivorous decapod that can become locally very dominant (Freire and GonzálezGurriarán, 1995). This species was found on every hard substratum transect and, thus, appears to be a characteristic species on natural and artificial hard substrata. The crabs were encountered everywhere on the wrecks and the platform anchorages close to the seafloor. $N$. puber was not reported in comparable regularity and density from wrecks in the Bristol Channel and in Belgian waters (Hiscock, 1980; Massin et al., 2002; Zintzen et al., 2008b). It is, therefore, unclear whether the species was actually absent from those wrecks. Alternatively, this species might not have been recorded in studies focussing exclusively on the fouling assemblages.

\subsection{FINO 1 jacket construction}

The MDM on the jacket construction varied in their composition most probably depending on the structural complexity of the various platform sections and their height above the seafloor. The anchorages are topographically more complex than the junctions in 5 and $15 \mathrm{~m}$ depth and were the most densely populated sections. Organisms are less exposed to hydrodynamic forces in lower than in upper water levels. Accordingly, shelter from predators and abiotic stress are probably responsible for the elevated abundances of MDM at the anchorages as compared to the junctions. The MDM on the anchorages was largely indistinguishable from the wreck fauna. Both structures are morphologically complex and provide shaded areas, which are important hiding and foraging habitats for fish (Bohnsack, 1989). Both artificial habitats, wrecks and the platform anchorages, were directly connected to the seafloor and formed a transition zone between hard and surrounding soft bottom habitats. Many mobile crustaceans inhabited the small ecotones at the edges of the artificial structures where they can exploit resources from both habitats. Accordingly, the voracious predators Cancer pagurus and Necora puber accumulated around the platform pylons and the ship remains where they most likely benefit from enhanced food supply provided by both the fouling organisms on the hard substrata (Freire and González-Gurriarán, 1995; Page et al., 1999) and the organisms from the surrounding soft bottom (Barros et al., 2001).

The higher sections of the jacket construction were inhabited by a comparably poor MDM assemblage. The assemblage from the $5 \mathrm{~m}$ junctions was quite similar to the soft sediment assemblage, although these sections are high up in the water column. This finding was mainly due to the occurrence of portunid swimming crabs at the $5 \mathrm{~m}$ junctions. Swimming crabs inhabit soft bottoms but display a circadian activity rhythm with most swimming activities during the daytime, e.g. in search for food (Abelló et al., 1991). Excursions into the water column might facilitate encounters with the platform structures and might, therefore, explain the occurrence of these soft bottom species on platform sections close to the sea surface. Predatory swimming crabs might have also been attracted by thick layers of the blue mussel (Mytilus edulis) in the shallow water sections of the platform (Krone et al., 2013). Dense aggregations of mussels provide habitat for diverse assemblages of associated faunal communities (Saier, 2002; Firstater et al., 2011) which are a valuable food sources for predatory decapods (Freire and González-Gurriarán, 1995).

\subsection{Soft bottoms}

The soft bottom was typically inhabited by flat fishes, gobies, hermit crabs (Pagurus bernhardus) and Liocarcinus spp. Some of these typical soft bottom taxa also occurred on small sandy patches within the wreck areas. However, densities were much smaller than on the open soft bottom indicating that the proximity of solid structures decreases habitat quality for typical soft substrata species, which might suffer from predation e.g. by the aggressive omnivore Necora puber (Freire and González-Gurriarán, 1995). The MDM on the seafloor close to the platform foundation showed some similarity to that of the open soft bottom but was clearly distinguishable from the latter by the occurrence of several hard substrata associated species venturing on the surrounding seafloor (especially N. puber and Cancer pagurus). Simultaneously, typical soft bottom species such as $P$. bernhardus, Callionymus spp. and flat fishes were found in this habitat confirming the transitional character of this habitat.

\subsection{Implications of offshore wind farms}

The MDM assemblages from wrecks and from the wind turbine foundation equivalent were largely identical with regard to the qualitative species composition. However, in terms of abundance of associated individuals, the jacket structure differs from a typical wreck. It should therefore be considered as a small wreck. The 'footprint' area of a wreck provides habitat e.g. for four (for Taurulus bubalis) to eight (for Cancer pagurus) times as many individuals as a jacket construction. The sections of the jacket which were higher up in the water column were only sparsely colonized by mobile fish and crustaceans and contributed, thus, only little new habitat for mobile fauna.

A future wind farm will most likely be more than just the sum of the single foundations. Within the planned deployment of wind farms, the foundations will be positioned less than $1000 \mathrm{~m}$ apart, a distance which is well within the migratory range of many mobile hard bottom species. This might increase the connectivity between the structures and promote migration of the organisms, thereby influencing the use of space and food resources. Moreover, unlike FINO 1, operating wind turbines vibrate and are thus emitting low frequency sound into the water (Lagardère et al., 1994; Wahlberg and Westerberg, 2005; Kikuchi, 2010). How the MDM will react to sound emission is still unknown.

In order to evaluate how offshore wind farms might create habitat for increasing MDM in a shelf sea on a larger spatial scale, it is essential to decide whether the artificial constructions enhance productivity or simply locally attract (redistribute) organisms ('Aggregation vs. Production debate'; Bohnsack, 1989; Page et al., 1999; Pickering and Whitmarsh, 1997; Osenberg et al., 2002; Powers et al., 2003). Although our investigations did not directly address this question, assumptions can be made based on the autecology of some species (Bohnsack, 1989). The population size of obligate hard substrata species such as Necora puber is limited in the German Bight by the availability of hard bottom sites. Any addition of hard substrata will allow for a population increase and therefore for additional biomass production. N. puber does not occur on soft substrata and is, thus, unlikely attracted from the nearby seafloor. Colonization occurs through planktonic larvae which might accumulate at the three dimensional artificial structure reacting to the thereby altered nearby current conditions (Falcão et al., 2009). This predatory species clearly benefits from the fouling organisms inhabiting the wrecks and jackets (Freire and González-Gurriarán, 1995; Page et al., 1999). Additional examples for production on wrecks and the platform structure are the fish species Taurulus bubalis and Ctenolabrus rupestris which are also absent from soft bottoms but are associated with hard substrata (Hilldén, 1981; King and Fives, 1983; Sundt and Jørstad, 1998). Species such as Cancer pagurus and Homarus gammarus probably aggregate on artificial hard substrata. These decapods visit rocky habitats in search for shelter and food thereby performing extensive migrations (Bennet and Brown, 1983; Krone 
and Schröder, 2011) and using artificial hard substrata as stepping stones within extensive soft bottom areas. We encountered numerous $C$. pagurus on the wrecks and the platform anchorages but only rarely on the open soft bottom. Some share of the larger individuals may have actively migrated and aggregated at the structures while smaller individuals most likely have settled on the structure as larvae (Bennet and Brown, 1983; Krone, 2012). Enhanced net food supply from the fouling assemblage on the underwater structures will locally enhance biomass production of these animals. Within areas similar to the German Bight, foundations like those of the FINO 1 platform create habitat for large predatory species, such as C. pagurus, N. puber and T. bubalis which are rarely found on the autochthonous soft bottom. Based on the findings at FINO 1, calculations indicate that 5000 turbine foundations will provide habitat that provides the carrying capacity for additional stocks of $C$. pagurus, $N$. puber and T. bubalis by ca. $25 \%, 165 \%$ and $121 \%$, respectively, of the present soft bottom and wreck fauna within the entire German Bight. Since the wind-power foundations also create potential food sources for MDM by harbouring tons of attached fouling organisms (Krone et al., 2013), the construction of the wind farms will lead to an increasing net productivity of obligatory and facultative MDM hard substratum species in soft bottom shelf sea regions. Especially further offshore in the North Sea where wrecks are rare, large wind farms may enhance the spreading of MDM hard bottom species even more. The design of some future wind farms entails the placement of bolder fields around the wind-power foundation to prevent scouring. Such structural additions will further enhance the suitability of the foundations as habitats and improve the function of wind farms as new MDM habitats (Wilson et al., 2010; Reubens et al., 2011). For this reason, the presently suggested potential of wind-power foundations for increasing the MDM stocks in shelf seas, shown for the FINO 1 platform which lacks a scour protection, should be taken as a conservative minimum estimate. However, future impact assessments of European wind-power projects should focus on to what extend the projected increase of the carrying capacity will result in additional net productivity of MDM. This is of importance to predict ecological system changes due to increased predatory stocks which might interact with the autochthonous soft bottom fauna. As a final outlook, sustainable fishery on new MDM stocks in wind-power farms might also be possible, if its production balance can be reliably estimated.

\section{Acknowledgements}

The investigation was funded by the Federal Ministry for Environment, Nature Conservation and Nuclear Safety (BMU) under the research project RAVE Ecology (0327689A) and coordinated by the Federal Maritime and Hydrographic Agency (BSH) and supervised by the Project Management Jülich. The conclusions of this paper are those of the authors and do not necessarily represent the views of the BMU. We like to thank the BSH, namely K. Blasche, A. Binder, A. Beiersdorf and M. Boethling for project coordination and H. Pietreck for the provision of wreck data. We thank the scientific diving centre of the Alfred Wegener Institute for Polar and Marine Research for logistical support and captain R. Voss and the crew of the research vessel FS Heincke for their help offshore. G. Dederer greatly assisted the diving supervisor and T. Alpermann, S. Fuhrmann, P. Krämer and F. Huber joined our scientific diving team. For improving the style of the manuscript we are very thankful to $B$. Schmidt, B. Ebbe and K. Boos.

\section{Appendix A. Supplementary data}

Supplementary data related to this article can be found at http:// dx.doi.org/10.1016/j.ecss.2013.03.012.

\section{References}

Abelló, P., Reid, D.G., Naylor, E., 1991. Comparative locomotory activity patterns in the Portunid crabs Liocarcinus holsatus and L. depurator. Journal of the Marine Biological Association of the United Kingdom 71, 1-10.

Arena, P.T., Jordan, L.K.B., Spieler, R.E., 2007. Fish assemblages on sunken vessels and natural reefs in southeast Florida, USA. Hydrobiologia 580, 157-171.

Barros, F., Underwood, A.J., Lindgarth, M., 2001. The influence of rocky reefs on structure of benthic macrofauna in nearby soft-sediments. Estuarine, Coastal and Shelf Science 52,191-199.

Baum, J.K., Worm, B., 2009. Cascading top-down effects of changing oceanic predator abundances. Journal of Animal Ecology 78, 699-714

Bennet, D.B., Brown, C.G., 1983. Crab (Cancer pagurus) migrations in the English Channel. Journal of the Marine Biological Association of the United Kingdom 63, 371-398.

Bohnsack, J.A., 1989. Are high densities of fishes at artificial reefs the result of habitat limitation or behavioral preference? Bulletin of Marine Science 44 , 631-645.

Bouma, S., Lengkeek, W., 2012. Benthic Communities on Hard Substrates of the Offshore Wind Farm Egmond an Zee (OWEZ)- Including Results of Samples Collected in Scour Holes. Final report 2012. Noordzeewind, Ijmuiden, The Netherlands, p. 80.

Castric, A., Chasse, C., 1991. Factorial analysis in the ecology of rocky subtidal areas near Brest (West Brittany, France). Journal of the Marine Biological Association of the United Kingdom 71, 515-536.

Clarke, K.R., Gorley, R.N., 2006. PRIMER V6: User Manual/Tutorial. PRIMER-E, Plymouth, United Kingdom.

Clarke, K.R., Warwick, R.M., 2001. Change in Marine Communities. PRIMER-E, Plymouth, United Kingdom.

Degraer, S., Brabant, R., Rumes, R., 2012. Offshore Wind Farms in the Belgian Part of the North Sea: Heading for an Understanding of Environmental Impacts. Roya Belgian Institute of Natural Sciences, Management Unit of the North Sea Mathematical Models, Marine Ecosystem Management Unit, p. 155.

Falcão, M., Santos, M.N., Drago, T., Serpa, D., Monteiro, C., 2009. Effects of artificial reefs (southern Portugal) on sediment-water transport of nutrients: importance of the hydrodynamic regime. Estuarine, Coastal and Shelf Science 83, 451-459.

Figge, K., 1981. BSH-map No. 2900: Sedimentverteilung in der Deutschen Bucht scale 1:250,000. Federal Maritime and Hydrographic Office (BSH), Hamburg, Germany, p. 13.

Firstater, F.N., Hidalgo, F.J., Lomovasky, B.J., Ramos, E., Gamero, P., Iribarne, O.O. 2011. Habitat structure is more important than nutrient supply in modifying mussel bed assemblage in an upwelling area of the Peruvian coast. Helgoland Marine Research 65, 187-196.

Forteath, G.N.R., Picken, G.B., Ralph, R., Willams, J., 1982. Marine growth studies on the North Sea oil platform Montrose Alpha. Marine Ecology Progress Series 8 61-68.

Freire, J., González-Gurriarán, E., 1995. Feeding ecology of the velvet swimming crab Necora puber in mussel raft areas of the Ría de Arousa (Galicia, NW Spain). Marine Ecology Progress Series 119, 139-154.

Harms, J., 1993. Check list of species (algae, invertebrates and vertebrates) found in the vicinity of the island of Helgoland (North Sea, German Bight) - a revision of recent records. Helgoländer Meeresuntersuchungen 47, 1-34.

Hilldén, N.-O., 1981. Territoriality and reproductive behaviour in the goldsinny, Ctenolabrus rupestris L. Behavioural Processes 6, 207-221.

Hiscock, K., 1980. Marine life on the wreck of the M.V. 'Robert'. Report of the Lundy Field Society 32, 40-44.

Hiscock, K., Sharrock, S., Highfield, J., Snelling, D., 2010. Colonization of an artificial reef in south-west England-ex-HMS 'Scylla'. Journal of the Marine Biological Association of the United Kingdom 90, 69-94.

IEA (International Energy Agency), 2008. IEA Wind Energy Annual Report 2007. IEA Paris, France, ISBN 0-9786383-2-8, p. 286.

Jørgensen, T. Løkkeborg, S., Soldal, A.V., 2002. Residence of fish in the vicinity of a decommissioned oil platform in the North Sea. ICES Journal of Marine Science $59,288-293$

Joschko, T.J., Buck, H.B., Gutow, L., Schröder, A., 2008. Colonization of an artificial hard substrate by Mytilus edulis in the German Bight. Marine Biology Research $4,350-360$

Kikuchi, R., 2010. Risk formulation for the sonic effects of offshore wind farms on fish in the EU region. Marine Pollution Bulletin 60, 172-177.

King, P.A., Fives, J.M., 1983. Littoral and benthic investigations on the west coast of Ireland-XVI. The biology of the long-spined sea scorpion Taurulus bubalis (Euphrasen, 1786) in the Galway Bay area. Proceedings of the Royal Irish Academy Section B - Biological Geological and Chemical Science 83, 215-239.

Kingsbury R.W.S.M., 1981. Marine fouling of North Sea installations. In: Marine Fouling of Offshore Structures, Session I \& II, vp. Marine Fouling of Offshore Structures Conference, 19-20 May 1981, London, United Kingdom, pp. 4-25.

Krone, R., Schröder, A., 2011. Wrecks as artificial lobster habitats in the German Bight. Helgoland Marine Research 65, 11-16.

Krone, R., 2012. Offshore Wind-power Reef Effects and Reef Fauna Roles. Ph.D. thesis. University Bremen, Germany, p. 211. published.

Krone, R., Gutow, L., Joschko, T.J., Schröder, A., 2013. Epifauna dynamics at an offshore foundation - implications of future wind-power farming in the North Sea. Marine Environmental Research 85, 1-12. 
Lagardère, J.P., Bégout, M.L., Lafaye, J.Y., Villotte, J.P., 1994. Influence of windproduced noise on orientation in the sole (Solea solea). Canadian Journal of Fisheries and Aquatic Sciences 51, 1258-1264.

Langhamer, O., Wilhelmsson, D., Engström, J., 2009. Artificial reef effect and fouling impacts on offshore wave power foundations and buoys - a pilot study. Estuarine, Coastal and Shelf Science 82, 426-432.

Lawton, P., 1989. Predatory interaction between the brachyuran crab Cancer pagurus and decapod crustacean prey. Marine Ecology Progress Series 52, 169-179.

Leewis, R., van Moorsel, G., Waardenburg, H., 2000. Shipwrecks on the Dutch continental shelf as artificial reefs. In: Jensen, A.C., Collins, K.J., Lockwood, A.P.M. (Eds.), Artificial Reefs in European Seas. Kluwer Academic Publishers, Dordrecht, The Netherlands, pp. 419-434.

Lindeboom, H.J., Kouwenhoven, H.J., Bergman, M.J.N., Bouma, S., Brasseur, S., Daan, R., Fijn, R.C., de Haan, D., Dirksen, S., van Hal, R., Lambers, R.H.R., Ter Hofstede, R., Krijgsveld, K.L., Leopold, M., Scheidat, M., 2011. Short-term ecological effects of an offshore wind farm in the Dutch coastal zone; a compilation. Environmental Research Letters 6 (035101), 13

Løkkeborg, S., Humborstad, O.-B., Jørgensen, T., Soldal, A.V., 2002. Spatio-temporal variations in gillnet catch rates in the vicinity of North Sea oil platforms. ICES Journal of Marine Science 59, 294-299.

Mascaró, M., Seed, R., 2001. Foraging behavior of juvenile Carcinus maenas (L.) and Cancer pagurus L. Marine Biology 139, 1135-1145.

Massin, C.L., Norro, A., Mallefet, J., 2002. Biodiversity of a wreck from Belgian continental shelf: monitoring using scientific diving. Preliminary results. Bulletin van het Koninklijk Belgisch Instituut voor Natuurwetenschappen, Biologie 72, 67-72.

McCauley, D.J., Micheli, F., Young, H.S., Tittensor, D.P., Brumbaugh, D.R., Madin, E.M.P., Holmes, K.E., Smith, J.E., Lotze, H.K., DeSalles, P.A., Arnold, S.N. Worm, B., 2010. Acute effects of removing large fish from a near-pristine coral reef. Marine Biology 157, 2739-2750.

Osenberg, C.W., St. Mary, C.M., Wilson, J.A., Lindberg, W.J., 2002. A quantitative framework to evaluate the attraction-production controversy. ICES Journal of Marine Science 59, 214-221.

Page, H.M., Dugan, J.E., Dugan, D.S., Richards, J.B., Hubbard, D.M., 1999. Effects of an offshore oil platform on the distribution and abundance of commercially important crab species. Marine Ecology Progress Series 185, 47-57.

Pickering, H., Whitmarsh, D., 1997. Artificial reefs and fisheries exploitation: a review of the 'attraction versus production' debate, the influence of design and its significance for policy. Fisheries Research 31, 39-59.

Powers, S.P., Grabowski, J.H., Peterson, C.H., Lindberg, W.J., 2003. Estimating enhancement of fish production by offshore artificial reefs: uncertainty exhibited by divergent scenarios. Marine Ecology Progress Series 264, 265-277.

RAVE (Research at alpha ventus), 2013. Interactive Map of Offshore Wind-energy in Europe. WWW page. http://rave.iwes.fraunhofer.de/rave/pages/map.

Relini, G., Relini, M., Torchia, G., De Angelis, G., 2002. Trophic relationships between fishes and an artificial reef. ICES Journal of Marine Science 59, 36-42.
Reubens, J.T., Degrear, S., Vincx, M., 2011. Aggregation and feeding behaviour of pouting (Trisopterus luscus) at wind turbines in the Belgian part of the North Sea. Fisheries Research 108, 223-227.

Saier, B., 2002. Subtidal and intertidal mussel beds (Mytilus edulis L.) in the Wadden Sea: diversity differences of associated epifauna. Helgoland Marine Research 56, 44-50.

Schleicher, S. (Ed.), 2012. European Offshore Wind Energy Projects-Status November 2012. Wind Energy Agency (WAB), Bremerhaven, Germany, p. 24. Report. http://wab.net/images/stories/PDF/downloads/WAB_EU_DE_Karten_ Tabellen_A4_131112.pdf.

Stephan, C.D., Lindquist, D.G., 1989. A comparative analysis of the fish assemblages associated with old and new shipwrecks and fish aggregating devices in Onslow Bay, North Carolina. Bulletin of Marine Science 44, 698-717.

Sundt, R.C., Jørstad, K.E., 1998. Genetic population structure of goldsinny wrasse, Ctenolabrus rupestris (L.), in Norway: implications for future management of parasite cleaners in the salmon farming industry. Fisheries Management and Ecology 5, 291-302.

Wahlberg, M., Westerberg, H., 2005. Hearing in fish and their reactions to sounds from offshore wind farms. Marine Ecology Progress Series 288, 295-309.

Whomersley, P., Picken, G.B., 2003. Long-term dynamics of fouling communities found on offshore installations in the North Sea. Journal of the Marine Biological Association of the United Kingdom 83, 897-901.

Wilhelmsson, D., Malm, T., Öhman, M.C., 2006. The influence of offshore windpower on demersal fish. ICES Journal of Marine Science 63, 775-784.

Wilhelmsson, D., Malm, T., 2008. Fouling assemblages on offshore wind-power plants and adjacent substrata. Estuarine, Coastal and Shelf Science 79, 459-466.

Wilson, J.C., Elliott, M., 2009. The habitat-creation potential of offshore wind farms. Wind Energy 12, 203-212.

Wilson, J.C., Elliott, M., Cutts, N.D., Mander, L., Mendao, V., Perez-Dominguez, R., Phelps, A., 2010. Coastal and offshore wind energy generation: is it environmentally benign? Energies 3, 1383-1422.

Wolfson, A., Van Blaricom, G., Davis, N., Lewbel, G.S., 1979. The marine life of an offshore oil platform. Marine Ecology Progress Series 1, 81-89.

Zintzen, V., Massin, C., Norro, A., Mallefet, J., 2006. Epifaunal inventory of two shipwrecks from the Belgian Continental Shelf. Hydrobiologia 555, 207-219.

Zintzen, V., Norro, A., Massin, C., Mallefet, J., 2008a. Temporal variation of Tubularia indivisa (Cnidaria, Tubulariidae) and associated epizoites on artificial habitat communities in the North Sea. Marine Biology 153, 405-420.

Zintzen, V., Norro, A., Massin, C., Mallefet, J., 2008b. Spatial variability of epifaunal communities from artificial habitat: shipwrecks in the Southern Bight of the North Sea. Estuarine, Coastal and Shelf Science 76, 327-344.

Zintzen, V., Massin, C., 2010. Artificial hard substrata from the Belgian part of the North Sea and their influence on the distributional range of species. Belgian Journal of Zoology 140, 20-29. 